\title{
Testosterone and Androstenedione Blood Production Rates in Normal Women and Women with Idiopathic Hirsutism or Polycystic Ovaries *
}

\author{
C. Wayne Bardin † and Mortimer B. Lipsett \\ (From the Endocrinology Branch, National Cancer Institute, Bethesda, Md.)
}

Summary. The average plasma testosterone concentration of women with either hirsutism or polycystic ovaries and hirsutism was higher $(p<0.01)$ than that of normal women although the ranges overlapped. Testosterone blood production rates averaged $830 \pm 120 \mathrm{SE}$ and $1,180 \pm 310 \mathrm{SE} \mu \mathrm{g}$ per day in the two groups of hirsute women and $230 \pm 33 \mathrm{SE} \mu \mathrm{g}$ per day in normal women. The ranges did not overlap.

The testosterone metabolic clearance rates of hirsute women $(1,090 \pm 140$ SE L per day) and of men (1,240 $\pm 136 \mathrm{SE} \mathrm{L}$ per day) were significantly higher than those of normal women ( $590 \pm 44 \mathrm{SE} \mathrm{L}$ per day). These differences persisted when the metabolic clearance rates were corrected for surface area. We suggest that testosterone metabolic clearance rates vary directly with some function of testosterone production.

The mean plasma androstenedione levels $(2.8 \pm 0.35 \mathrm{SE}$ and $2.8 \pm 0.30 \mathrm{SE}$ $\mu \mathrm{g}$ per $\mathrm{L})$ and production rates $(6,060 \pm 450 \mathrm{SE}$ and $7,360 \pm 345 \mathrm{SE} \mu \mathrm{g}$ per day) of the women with hirsutism or polycystic ovaries, respectively, were significantly higher than those of normal women (1.5 $\pm 0.22 \mathrm{SE} \mu \mathrm{g}$ per L; 3,300 $\pm 830 \mathrm{SE} \mu \mathrm{g}$ per day). The androstenedione metabolic clearance rates were the same in each group. Plasma androstenedione was the precursor of $49 \%$ of plasma testosterone in normal women and of $26 \%$ of plasma testosterone in hirsute women. Thus, $74 \%$ of the plasma testosterone in these subjects must have been either secreted or derived from a precursor that did not enter the plasma androstenedione pool.

\section{Introduction}

Study of virilization and hirsutism received new impetus with the introduction of accurate methods for measuring plasma testosterone ${ }^{1}$ levels. In several series of hirsute women $(1-6)$, the average

* Submitted for publication November 28, 1966; accepted February 2, 1967.

A preliminary report of this work was presented at the Forty-eighth Meeting of the Endocrine Society, June 20, 1966.

$\dagger$ Address requests for reprints to Dr. C. Wayne Bardin, Endocrinology Branch, National Cancer Institute, Bethesda, Md. 20014.

1 The following trivial names have been used: testosterone, 17 $\beta$-hydroxy-4-androsten-3-one; androstenedione, 4-androsten-3,17-dione; dehydroepiandrosterone, 3 $\beta$-hydroxy-5-androsten-17-one. plasma testosterone concentration was high, but in each series some of the subjects had normal levels. The role of plasma androstenedione has not been evaluated in hirsute women, and there is no comprehensive study of androgen production rates in such patients. We have therefore measured testosterone and androstenedione plasma levels and production rates in normal women and in women with idiopathic hirsutism and hirsutism associated with polycystic ovaries. Using the model developed by Horton and Tait (7), we have estimated the contribution of androstenedione production to the testosterone production rate and have shown that the excess testosterone is secreted as well as produced from plasma androstenedione. Our finding that the blood testosterone production 
TABLE I

Clinical summary

\begin{tabular}{|c|c|c|c|c|c|c|c|c|c|}
\hline $\begin{array}{l}\text { Sub- } \\
\text { ject }\end{array}$ & Age & Weight & Height & $\begin{array}{l}\text { Body } \\
\text { surface }\end{array}$ & $\underset{\text { ism* }}{\text { Hirsut- }}$ & Menses† & $\begin{array}{l}\text { Ovula- } \\
\text { tory }\end{array}$ & $\begin{array}{l}\text { Ovarian } \\
\text { size }\end{array}$ & $\begin{array}{l}\text { Urinary } \\
17 \text {-keto- } \\
\text { steroids }\end{array}$ \\
\hline & years & kg & $\mathrm{cm}$ & $m^{2}$ & & & & $\mathrm{~cm}$ & $m g / d a y$ \\
\hline \multicolumn{10}{|c|}{ Ia. Normal ovulatory women } \\
\hline $\begin{array}{l}1 \\
2 \\
3 \\
4 \\
5\end{array}$ & $\begin{array}{l}22 \\
33 \\
21 \\
26 \\
33\end{array}$ & $\begin{array}{l}59 \\
50 \\
40 \\
55 \\
55\end{array}$ & $\begin{array}{l}158 \\
164 \\
165 \\
170 \\
159\end{array}$ & $\begin{array}{l}1.59 \\
1.52 \\
1.39 \\
1.62 \\
1.54\end{array}$ & . & $\begin{array}{l}\mathbf{N} \\
\mathbf{N} \\
\mathbf{N} \\
\mathbf{N} \\
\mathbf{N}\end{array}$ & $\begin{array}{l}\text { Yes } \\
\text { Yes } \\
\text { Yes } \\
\text { Yes } \\
\text { Yes }\end{array}$ & $\begin{array}{l}\mathbf{N} \\
\mathbf{N} \\
\mathbf{N} \\
\mathbf{N} \\
\mathbf{N}\end{array}$ & \\
\hline \multicolumn{10}{|c|}{ Ib. Anovulatory women } \\
\hline $\begin{array}{l}6 \\
7 \\
8 \\
9\end{array}$ & $\begin{array}{l}28 \\
22 \\
64 \\
35\end{array}$ & $\begin{array}{r}61 \\
68 \\
61 \\
100\end{array}$ & $\begin{array}{l}158 \\
156 \\
165 \\
157\end{array}$ & $\begin{array}{l}1.61 \\
1.67 \\
1.66 \\
2.00\end{array}$ & & $\begin{array}{l}\mathrm{N} \\
\mathrm{N} \\
\mathrm{A} \\
\mathrm{A}\end{array}$ & $\begin{array}{l}\text { No } \\
\text { No } \\
\text { No } \\
\text { No }\end{array}$ & $\begin{array}{l}\mathbf{N} \\
\mathbf{N} \\
\mathrm{N} \\
\mathrm{N}\end{array}$ & $\begin{array}{r}12 \\
6 \\
8\end{array}$ \\
\hline \multicolumn{10}{|c|}{ II. Women with idiopathic hirsutism } \\
\hline $\begin{array}{l}10 \\
11 \\
12 \\
13 \\
14 \\
15 \\
16 \\
17\end{array}$ & $\begin{array}{l}24 \\
17 \\
18 \\
23 \\
31 \\
20 \\
31 \\
25\end{array}$ & $\begin{array}{l}85 \\
54 \\
60 \\
66 \\
49 \\
92 \\
72 \\
97\end{array}$ & $\begin{array}{l}163 \\
163 \\
165 \\
172 \\
153 \\
165 \\
165 \\
165\end{array}$ & $\begin{array}{l}1.89 \\
1.56 \\
1.65 \\
1.77 \\
1.43 \\
1.97 \\
1.78 \\
2.01\end{array}$ & $\begin{array}{l}4+ \\
2+\ddagger \\
3+ \\
2+ \\
3+ \\
1+ \\
1+ \\
2+\end{array}$ & $\begin{array}{l}\mathrm{N} \\
\mathrm{N} \\
\mathrm{N} \\
\mathrm{N} \\
\mathrm{O} \\
\mathrm{O} \\
\mathrm{O} \\
\mathrm{A}\end{array}$ & $\begin{array}{l}\text { Yes } \\
\text { Yes } \\
\text { Yes } \\
\text { Yes } \\
\text { No } \\
\text { No } \\
\text { No } \\
\text { No }\end{array}$ & $\begin{array}{c}\mathrm{N} \\
\mathrm{N} \\
\mathrm{N} \\
\mathrm{N} \\
3 \times 2 \times 3 \\
3 \times 2 \times 2 \\
4 \times 2 \times 2\end{array}$ & $\begin{array}{r}18 \\
11 \\
11 \\
13 \\
6 \\
6 \\
20 \\
12\end{array}$ \\
\hline \multicolumn{10}{|c|}{ III. Women with polycystic ovaries } \\
\hline $\begin{array}{l}18 \\
19 \\
20 \| \\
21 \\
22\end{array}$ & $\begin{array}{l}33 \\
35 \\
29 \\
25 \\
35\end{array}$ & $\begin{array}{r}81 \\
117 \\
65 \\
81 \\
101\end{array}$ & $\begin{array}{l}164 \\
164 \\
175 \\
172 \\
162\end{array}$ & $\begin{array}{l}1.86 \\
2.18 \\
1.78 \\
1.93 \\
2.02\end{array}$ & $\begin{array}{l}3+\neq 8 \\
3+ \\
2+ \\
1+ \\
3+t\end{array}$ & $\begin{array}{l}\mathrm{O} \\
\mathrm{O} \\
\mathrm{N} \\
\mathrm{O} \\
\mathrm{O}\end{array}$ & $\begin{array}{l}\text { No } \\
\text { No } \\
\text { Yes } \\
\text { No } \\
\text { No }\end{array}$ & $\begin{array}{l}4 \times 6 \times 4 \\
4 \times 3 \times 3 \\
6 \times 6 \times 4 \\
3 \times 2 \times 2 \\
4 \times 2 \times 2\end{array}$ & $\begin{array}{r}8 \\
14 \\
23 \\
9 \\
10\end{array}$ \\
\hline
\end{tabular}

* Facial hirsutism was graded $1+$ for each portion of the face involved (side burns, upper lip, chin) and $4+$ if the entire beard area was involved. All subjects had a heavy growth of hair on trunk and extremities.

+ Abbreviations: $\mathrm{N}=$ normal; $\mathrm{O}=$ oligomenorrhea; $\mathrm{A}=$ amenorrhea.

¥ Slight temporal balding.

$\$$ Clitoromegaly.

Patient studied after wedge resection of ovaries.

rate was high in each hirsute woman is the only consistent physiologic difference between normal and hirsute women that has been observed.

\section{Methods}

Subjects. The normal subjects volunteered for these studies. Group Ia was composed of five women with normal ovulatory menses. Group Ib contained four nonhirsute subjects: one was receiving oral contraceptives 2 (Patient 6); one had received oral contraceptives ${ }^{2} 5$ months previously and was now anovulatory (Patient 7); one had carcinoma of the cervix and was postmenopausal (Patient 8); and one patient had secondary idiopathic amenorrhea (Patient 9). Group II comprised eight women with complaints of hirsutism. In four of them the ovaries were assumed to be normal on the basis of regular ovulatory menses. In three of the four patients with irregular anovulatory cycles in whom culdoscopy

2 Norethynodrel, $5 \mathrm{mg}$ per day, and mestranol, $0.075 \mathrm{mg}$ per day. was performed (Patients 14, 15, 17) the ovaries were grossly and histologically normal. Group III contained five hirsute patients with histologically characteristic polycystic ovaries. When groups II and III are combined, they will be referred to as the hirsute subjects. These clinical data are summarized in Table I. Testosterone metabolic clearance rates were determined in six normal men.

All subjects used in this study had normal 24-hour urinary 17-hydroxycorticoid excretion that was suppressed by $2 \mathrm{mg}$ of dexamethasone daily for 3 days. Ovulation was diagnosed either by endometrial biopsy or urinary pregnanediol excretion. Thyroid and liver function tests were normal in all subjects. Urinary steroids measured were as follows: 17-ketosteroids (8), 17-hydroxycorticoids (9), and pregnanediol (10).

Reagents. Solvents were analytical grade and were distilled before use. Androstenedione-1,2-8 $\mathrm{H}$ ( $5 \mathrm{c}$ per mmole), androstenedione-4-4 $\mathrm{C}$ (50 $\mathrm{mc}$ per mmole), testosterone- $7 \alpha^{-3} \mathrm{H}$ (10 c per mmole), and testosterone$4{ }^{14} \mathrm{C}$ ( $50 \mathrm{mc}$ per mmole) were obtained commercially ${ }^{3}$

${ }^{3}$ New England Nuclear Corp., Boston, Mass. 
TABLE II

Chromatographic systems

\begin{tabular}{lll}
\hline System & Support & \multicolumn{1}{c}{ Solvents } \\
\hline $\mathrm{BM}_{1}$ & Silica gel & Benzene:methanol $(9: 1)$ \\
$\mathrm{BE}_{4}$ & Silica gel & Benzene:ethyl acetate (6:4) \\
$\mathrm{BE}_{2}$ & Silica gel & Benzene:ethyl acetate (8:2) \\
$\mathrm{Bush}_{2}$ & Paper & Ligroin:methanol:water $(10: 7: 3)$ \\
\hline
\end{tabular}

and further purified by thin layer chromatography in systems $\mathrm{BM}$ and $\mathrm{BE}$ ( (Table II). To test for purity of the labeled steroids, we added a portion of each to 200 $\mu \mathrm{g}$ of authentic steroid and carried through the procedure outlined in Figure 1. The specific activity was estimated by measuring the mass of steroid by absorption at $240 \mathrm{~m} \mu$ in ethanol and radioactivity by liquid scintillation spectrometry. The specific activity of each steroid remained constant after successive chromatography as the acetate, free alcohol, and 17-ketone.

Chromatography. Thin layer chromatography was performed on $20-\times 20-\mathrm{cm}$ glass plates coated with $25 \mathrm{~mm}$ of Brinkmann Porter silica gel $\mathrm{GH}_{254}$. Whatman $3 \mathrm{MM}$ was used for paper chromatography. The chromatography

\section{Plasma Extract}

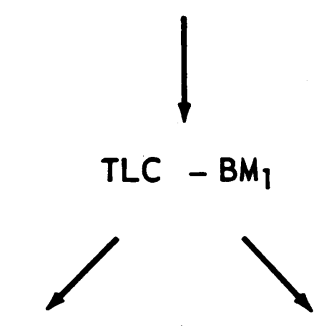

\section{Testosterone}

1. Bush $A_{2}-16$ hrs

2. Acetylation

3. $\mathrm{TLC}-\mathrm{BE}_{2}$

4. Specific activity

5. Saponification

6. $T L C-B E_{4}$

7. Specific activity

8. Oxidation

9. $T_{L C ~ B E_{4}}$

10. Specific activity

\section{Androstenedione}

1. Acetylation

2. Bush $A_{2}-6$ hrs

3. Reduction to testosterone

4. TLC BE 4

5. Specific activity

6. Acetylation

7. $T L C-B E_{2}$

8. Specific activity

9. Saponification

10. $T L C-B_{2}$

11. Specific activity

12. Oxidation

13. TLC - BM,

14. Specific activity

Fig. 1. Purification of PLASMa extracts for estiMATION OF ISOTOPIC TESTOSTERONE AND ANDROSTENEDIONE. TLC $=$ thin layer chromatography. Steps 12 and 13 were performed on 9 samples and produced no change in specific activity. systems are listed in Table II. Gas-liquid chromatography and collection of the samples for radioactivity measurements were performed as described previously (11).

Plasma steroids. Forty $\mathrm{ml}$ of heparinized blood was obtained for plasma steroid levels immediately before determination of the metabolic clearance rates. Plasma testosterone and androstenedione concentration was measured by a modification (12) of the double isotope technique reported from this laboratory (11). Plasma testosterone and androstenedione samples of $0.007 \mu \mathrm{g}$ can be measured with theoretical precisions of $35 \%$ and $22 \%$, respectively. The method blanks for $20 \mathrm{ml}$ of plasma with an over-all recovery of $20 \%$ were $0.010 \mu \mathrm{g}$ per 100 $\mathrm{ml}$ for testosterone and $0.0025 \mu \mathrm{g}$ per $100 \mathrm{ml}$ for androstenedione and have been subtracted from the reported plasma levels.

Metabolic clearance rates. The metabolic clearance rates of testosterone $\left(\mathrm{MCR}^{\mathrm{T}}\right)$ and of androstenedione $\left(\mathrm{MCR}^{\mathbf{A}}\right)$ were measured by the technique of Horton and Tait (7), and their abbreviations are used. All subjects were studied under basal conditions. Approximately 10 to $15 \mu \mathrm{c}$ of androstenedione- ${ }^{3} \mathrm{H}$ and 0.25 to $0.5 \mu \mathrm{c}$ of testosterone- ${ }^{14} \mathrm{C}$ were injected intravenously in $20 \mathrm{ml}$ of $5 \%$ ethanol in saline as a priming dose, and starting $30 \mathrm{~min}$ utes later, double these quantities were given as a constant infusion for 90 minutes in $170 \mathrm{ml}$ of $5 \%$ ethanol in saline. With the infusion of androstenedione $-{ }^{3} \mathrm{H}$ and testosterone $-{ }^{14} \mathrm{C}$ at a disintegrations per minute ratio of $30: 1$, sufficient ${ }^{3} \mathrm{H}$ and ${ }^{14} \mathrm{C}$ counts were present in $20 \mathrm{ml}$ of plasma to determine the metabolic clearance of both steroids and the conversion ratio of androstenedione to testosterone but not the conversion ratio of testosterone to androstenedione. In one patient (No. 8) the infusion was extended for 12 hours. In two additional subjects (Patients 3 and 17), the isotopes were reversed, and $7 \mu \mathrm{c}$ of androstenedione- $-4-{ }^{14} \mathrm{C}$ and $2.5 \mu \mathrm{c}$ of testosterone- $7 \alpha-{ }^{3} \mathrm{H}$ were given as a priming dose, and after 30 minutes twice these quantities were infused over 90 minutes. These data are presented in Table III.

The radioactive steroids were infused with a Bowman infusion pump equipped with a siliconized latex pump tube and Teflon tubing. The latex pump tubing was replaced after every fifth infusion. The tubing effluent was monitored at frequent intervals, generally three to five times during the infusion, and the actual rate of infusion of labeled steroids agreed closely with the calculated rate in each instance. The MCR was calculated from the rate of infusion of the isotope divided by the concentration of isotope in the specific steroid per volume of plasma.

Isotopic testosterone and androstenedione concentrations were determined by reverse isotope dilution on 40 $\mathrm{ml}$ of heparinized blood obtained at 50,70 , and 86 minutes of the infusion. The plasma was separated within 30 minutes, and $200 \mu \mathrm{g}$ each of testosterone and androstenedione was added to the plasma. The plasma samples were extracted twice with 2 vol of ether: chloroform (3:1) after the addition of $1 \mathrm{ml}$ of $1 \mathrm{~N} \mathrm{NaOH}$ per 20 $\mathrm{ml}$ of plasma. The extracts were washed with water, 
TABLE III

Infusion rates and plasma concentration of isotopic steroids

\begin{tabular}{|c|c|c|c|c|c|c|c|c|c|}
\hline \multirow[b]{2}{*}{ Sub- } & \multicolumn{2}{|c|}{ Infusion } & \multicolumn{2}{|c|}{ Plasma* } & \multirow[b]{2}{*}{ Subject } & \multicolumn{2}{|c|}{ Inf usion } & \multicolumn{2}{|c|}{ Plasma* } \\
\hline & $\begin{array}{c}\text { tenedione- } \\
{ }^{3} \mathrm{H}\end{array}$ & $\begin{array}{c}\text { Testos- } \\
\text { terone-14 }\end{array}$ & $\begin{array}{l}\text { tenedione- } \\
{ }^{3} \mathrm{H}\end{array}$ & $\begin{array}{c}\text { Testos- } \\
\text { terone-14C }\end{array}$ & & $\begin{array}{c}\text { tenedione- } \\
{ }^{\mathbf{S}} \mathrm{H}\end{array}$ & $\begin{array}{l}\text { Testos- } \\
\text { terone-14C }\end{array}$ & ${ }^{3} \mathrm{H}$ & $\begin{array}{l}\text { Testos- } \\
\text { terone-14C }\end{array}$ \\
\hline & $\begin{array}{l}d p m / h r \\
\times 10^{7}\end{array}$ & $\begin{array}{l}d p m / h r \\
\times 10^{6}\end{array}$ & $\stackrel{d p m / L}{\times 10^{5}}$ & $\begin{array}{l}d p m / L \\
\times 10\end{array}$ & & $\begin{array}{l}d p m / h r \\
\times 10^{7}\end{array}$ & $\stackrel{d p m / h r}{\times 10^{6}}$ & $\underset{\times 10^{5}}{d p m / L}$ & $\stackrel{d p m / L}{\times 10^{4}}$ \\
\hline 1 & 4.31 & 1.41 & 6.9 & 6.40 & 12 & 5.38 & 1.69 & 5.43 & 6.05 \\
\hline 2 & 5.99 & 1.31 & 4.78 & 5.23 & 13 & 4.74 & 1.46 & 5.55 & 3.14 \\
\hline $3 \dagger$ & 1.82 & 6.80 & 1.93 & 21.4 & 14 & 4.39 & 1.44 & 7.06 & 5.87 \\
\hline 4 & 4.21 & 1.42 & 5.96 & 6.45 & 15 & 5.38 & 1.69 & 5.08 & 2.51 \\
\hline 5 & 4.08 & 1.59 & 4.78 & 7.05 & 16 & 4.00 & 1.59 & 4.46 & 3.75 \\
\hline 6 & 2.68 & 1.17 & 2.76 & 7.67 & $17 \dagger$ & 1.82 & 6.80 & 1.68 & 9.31 \\
\hline 7 & 5.04 & 2.35 & 4.00 & 6.00 & 18 & 4.85 & 2.60 & 3.10 & 3.94 \\
\hline 8 & & 0.434 & & 1.73 & 19 & 5.85 & 1.32 & 4.18 & 3.00 \\
\hline 9 & & 18.0 & & 34.0 & 20 & 4.70 & 1.79 & 3.32 & 5.26 \\
\hline 10 & 4.75 & 2.51 & 3.83 & 6.06 & 21 & 4.90 & 1.55 & 6.29 & 4.98 \\
\hline 11 & 2.50 & 1.45 & 2.78 & 3.72 & 22 & 4.76 & 1.63 & 4.83 & 2.94 \\
\hline
\end{tabular}

* Mean of the three values obtained at 50,70, and 86 minutes of the infusion.

$\dagger$ Androstenedione- ${ }^{14} \mathrm{C}$ and testosterone- ${ }^{3} \mathrm{H}$ were infused in these patients.

dried, and purified by chromatography and derivative formation as outlined in Figure 1. Oxidation was carried out with $0.2 \%$ chromic acid in glacial acetic acid for 10 minutes and reduction with freshly prepared $2 \%$ potassium borohydride in water for 20 seconds. Acetylation was performed with acetic anhydride in pyridine and saponification with $0.15 \mathrm{~N} \mathrm{NaOH}$ in $80 \%$ methanol under $\mathrm{N}_{2}$ overnight. After chromatography of each derivative (Figure 1) the specific activity of both plasma steroids was determined as outlined above. The plasma concentrations of isotopes in testosterone and androstenedione were calculated from the recovery of added unlabeled steroid.

Evidence that the infused steroids reached equilibrium during the 90 -minute infusion was provided by the constant level of radioactive testosterone and androstenedione observed in the plasma samples at 50,70 , and $86 \mathrm{~min}$ utes. In one patient (No. 8), continuing the infusion for 12 hours produced no change in the observed radioactive testosterone levels. In each subject the mean plasma concentrations for both testosterone and androstenedione were calculated, and the per cent deviation of each sample from the mean was determined. After infusion of testosterone $-{ }^{14} \mathrm{C}$ and androstenedione- ${ }^{8} \mathrm{H}$ the deviation of individual samples from the mean was $\pm 1.1 \%$ for ${ }^{14} \mathrm{C}$ in testosterone, $\pm 2 \%$ for ${ }^{8} \mathrm{H}$ in androstenedione, and $\pm 6 \%$ for ${ }^{8} \mathrm{H}$ in testosterone. These analyses demonstrated no significant trend in the plasma isotopic steroid levels.

${ }^{8} \mathrm{H} /{ }^{14} \mathrm{C}$ of urinary testosterone glucuronoside. After each infusion, urine was collected for 2 days and pooled. One-tenth of the pool from each of six subjects was extracted with 2 vol of ether and then hydrolyzed with beef liver glucuronidase (Ketodase). The freed steroids were extracted with 6 vol of dichloromethane after addition of $50 \mu \mathrm{g}$ of testosterone. The extracts were washed with $0.1 \mathrm{~N} \mathrm{NaOH}$ and water and then partitioned between heptane and $80 \%$ ethanol. The heptane was discarded; the ethanol concentration was reduced to $20 \%$, and the testosterone was extracted with 8 vol of carbon tetrachloride. These extracts were purified as in Figure 1. One-third of the sample was counted at steps 4 and 10 , and the ${ }^{8} \mathrm{H} /{ }^{14} \mathrm{C}$ of the remaining one-third was determined on the effluent after gas-liquid chromatography. The ${ }^{8} \mathrm{H} /{ }^{14} \mathrm{C}$ ratios were the same at step 10 and after gas-liquid chromatography.

Radioactivity measurement. Counting was performed with a Packard Tri-Carb liquid scintillation spectrometer, model 4322 , operating at $25 \%$ efficiency for ${ }^{3} \mathrm{H}$ and at $50 \%$ efficiency for ${ }^{14} \mathrm{C}$. Discriminator and gain settings were such that less than $0.1 \%$ of the ${ }^{3} \mathrm{H}$ was counted in the ${ }^{14} \mathrm{C}$ channel, and $13 \%$ of the ${ }^{14} \mathrm{C}$ was counted in the ${ }^{8} \mathrm{H}$ channel. With a single isotope, sufficient counts were accumulated to give standard errors of less than $2 \%$. When two isotopes were measured, the samples were counted four times for 50 minutes, and the standard errors for ${ }^{8} \mathrm{H}$ and ${ }^{14} \mathrm{C}$ were less than $2 \%$. The standard error of the ${ }^{3} \mathrm{H} /{ }^{14} \mathrm{C}$ ratio of urinary testosterone glucuronoside was less than $4 \%$.

Calculations. The symbols and calculations for the several parameters of the testosterone-androstenedione system are those of Horton and Tait (7). The superscripts indicate the steroid, the subscripts the compartment. The symbol $z$ refers to the isotope in testosterone and $\mathrm{x}$ to the isotope in androstenedione. The formulas used are as follows:

$$
\mathrm{MCR}^{\mathrm{T}}=\mathrm{Rz}^{\mathrm{T}} / \mathrm{z}^{\mathrm{T}} \text { and } \mathrm{MCR}^{\mathrm{A}}=\mathrm{Rx}^{\mathrm{A}} / \mathrm{x}^{\mathrm{A}} \text {, }
$$

where $\mathrm{Rz}^{\mathrm{T}}$ is the disintegrations per minute of testosterone infused per unit time and $z^{\mathbf{T}}$ is the concentration of isotope in testosterone in disintegrations per minute per unit volume of plasma. The androstenedione expressions are analogous.

$$
\mathrm{P}_{B^{T}}=M^{\mathbf{T}} \times \mathrm{i}^{\mathbf{T}} \text { and } \mathrm{P}_{\mathbf{B}^{\mathbf{A}}}=\mathrm{MCR}^{\mathbf{A}} \times \mathrm{i}^{\mathbf{A}} \text {, }
$$

where $P_{B}{ }^{T}$ is the blood testosterone production rate and $i^{T}$ is the blood testosterone concentration.

$$
C_{B B}{ }^{A T}=x^{T} / x^{A},
$$


TABLE IV

Concentrations, production rates, and interconversion of plasma testosterone and androstenedione*

\begin{tabular}{|c|c|c|c|c|c|c|c|c|c|}
\hline Subject & $\begin{array}{l}\text { Plasma } \\
\text { testosterone }\end{array}$ & $\mathbf{M C R}^{\mathrm{T}}$ & $\mathbf{P}_{\mathbf{B}} \mathbf{T}$ & $\begin{array}{c}\text { Plasma } \\
\text { andros- } \\
\text { tenedione }\end{array}$ & MCRA & $\mathrm{PB}^{A}$ & $\mathbf{x}^{\mathrm{T}} / \mathbf{x}^{\mathbf{A}}$ & {$[\rho]_{\mathbf{B B}^{A} \mathbf{T}}$} & 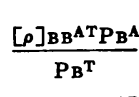 \\
\hline \multicolumn{10}{|c|}{$\begin{array}{cr}\mu g / L & L / d a y \\
\text { Ia. Normal ovulatory women }\end{array}$} \\
\hline $\begin{array}{l}1 \\
2 \\
3 \\
4 \\
5\end{array}$ & $\begin{array}{l}0.25 \\
0.36 \\
0.36 \\
0.39 \\
0.62\end{array}$ & $\begin{array}{l}530 \\
600 \\
760 \\
530 \\
540\end{array}$ & $\begin{array}{l}130 \\
220 \\
260 \\
210 \\
330\end{array}$ & $\begin{array}{l}1.1 \\
2.1 \\
0.9 \\
1.7 \\
1.8\end{array}$ & $\begin{array}{l}1,500 \\
3,000 \\
2,120 \\
1,700 \\
2,050\end{array}$ & $\begin{array}{l}1,700 \\
6,300 \\
1,890 \\
2,900 \\
3,700\end{array}$ & $\begin{array}{l}0.093 \\
0.16 \\
0.11 \\
0.095 \\
0.12\end{array}$ & $\begin{array}{l}0.033 \\
0.032 \\
0.039 \\
0.030 \\
0.032\end{array}$ & $\begin{array}{l}0.45 \\
0.93 \\
0.28 \\
0.41 \\
0.35\end{array}$ \\
\hline $\begin{array}{l}\text { Mean } \\
\text { SD } \\
\text { SE }\end{array}$ & $\begin{array}{r}0.40 \\
\pm 0.13 \\
\pm 0.06\end{array}$ & $\begin{array}{r}590 \\
\pm 98 \\
\pm 44\end{array}$ & $\begin{array}{r}230 \\
\pm 73 \\
\pm 33\end{array}$ & $\begin{array}{c}1.5 \\
\pm 0.50 \\
\pm 0.22\end{array}$ & $\begin{array}{l}2,070 \\
\pm 577 \\
\pm 260\end{array}$ & $\begin{array}{r}3,300 \\
\pm 1,860 \\
\pm 830\end{array}$ & $\begin{array}{c}0.12 \\
\pm 0.025 \\
\pm 0.011\end{array}$ & $\begin{array}{r}0.033 \\
\pm 0.003 \\
\pm 0.001\end{array}$ & $\begin{array}{r}0.49 \\
\pm 0.29 \\
\pm 0.11\end{array}$ \\
\hline \multicolumn{10}{|c|}{ Ib. Anovulatory women } \\
\hline $\begin{array}{l}6 \\
7 \\
8 \\
9\end{array}$ & $\begin{array}{l}0.53 \\
1.4 \\
0.32 \\
0.90\end{array}$ & $\begin{array}{r}370 \\
940 \\
600 \\
1,270\end{array}$ & $\begin{array}{r}200 \\
1,320 \\
190 \\
1,140\end{array}$ & $\begin{array}{l}1.6 \\
2.4 \\
0.9\end{array}$ & $\begin{array}{l}2,330 \\
3,020\end{array}$ & $\begin{array}{l}3,700 \\
7,250\end{array}$ & $\begin{array}{l}0.25 \\
0.085\end{array}$ & $\begin{array}{l}0.040 \\
0.026\end{array}$ & $\begin{array}{l}0.76 \\
0.15\end{array}$ \\
\hline \multicolumn{10}{|c|}{ II. Women with idiopathic hirsutism } \\
\hline $\begin{array}{l}10 \\
11 \\
12 \\
13 \\
14 \\
15 \\
16 \\
17\end{array}$ & $\begin{array}{l}0.90 \\
1.08 \\
1.01 \\
0.71 \\
0.99 \\
0.35 \\
0.54 \\
0.90\end{array}$ & $\begin{array}{r}990 \\
920 \\
670 \\
1,100 \\
590 \\
1,610 \\
1,020 \\
1,750\end{array}$ & $\begin{array}{r}890 \\
990 \\
680 \\
780 \\
580 \\
560 \\
550 \\
1,580\end{array}$ & $\begin{array}{l}1.9 \\
3.5 \\
2.3 \\
2.2 \\
5.1 \\
1.8 \\
2.9 \\
2.7\end{array}$ & $\begin{array}{l}2,980 \\
2,250 \\
2,380 \\
2,050 \\
1,490 \\
2,520 \\
2,150 \\
2,610\end{array}$ & $\begin{array}{l}5,510 \\
7,700 \\
5,430 \\
4,520 \\
7,600 \\
4,540 \\
6,100 \\
7,040\end{array}$ & $\begin{array}{l}0.058 \\
0.096 \\
0.084 \\
0.045 \\
0.092 \\
0.040 \\
0.075 \\
0.068\end{array}$ & $\begin{array}{l}0.019 \\
0.040 \\
0.024 \\
0.024 \\
0.036 \\
0.026 \\
0.036 \\
0.046\end{array}$ & $\begin{array}{l}0.12 \\
0.31 \\
0.19 \\
0.14 \\
0.47 \\
0.21 \\
0.40 \\
0.20\end{array}$ \\
\hline $\begin{array}{l}\text { Mean } \\
\text { SD } \\
\text { SE }\end{array}$ & $\begin{array}{r}0.81 \\
\pm 0.75 \\
\pm 0.09\end{array}$ & $\begin{array}{l}1,080 \\
\pm 410 \\
\pm 145\end{array}$ & $\begin{array}{r}830 \\
\pm 340 \\
\pm 120\end{array}$ & $\begin{array}{c}2.8 \\
\pm 0.98 \\
\pm 0.35\end{array}$ & $\begin{array}{l}2,300 \\
\pm 440 \\
\pm 160\end{array}$ & $\begin{array}{r}6,060 \\
\pm 1,280 \\
\pm 450\end{array}$ & $\begin{array}{r}0.070 \\
\pm 0.017 \\
\pm 0.006\end{array}$ & $\begin{array}{r}0.031 \\
\pm 0.009 \\
\pm 0.003\end{array}$ & $\begin{array}{r}0.26 \\
\pm 0.13 \\
\pm 0.04\end{array}$ \\
\hline \multicolumn{10}{|c|}{ III. Women with polycystic ovaries } \\
\hline $\begin{array}{l}18 \\
19 \\
20 \\
21 \\
22\end{array}$ & $\begin{array}{l}0.51 \\
1.21 \\
0.70 \\
0.82 \\
1.98\end{array}$ & $\begin{array}{r}1,580 \\
1,060 \\
820 \\
750 \\
1,330\end{array}$ & $\begin{array}{r}810 \\
1,280 \\
570 \\
620 \\
2,640\end{array}$ & $\begin{array}{l}2.2 \\
2.3 \\
1.9 \\
3.4 \\
3.4\end{array}$ & $\begin{array}{l}3,720 \\
3,310 \\
3,400 \\
1,870 \\
2,360\end{array}$ & $\begin{array}{l}8,100 \\
7,600 \\
6,700 \\
6,400 \\
8,000\end{array}$ & $\begin{array}{l}0.065 \\
0.120 \\
0.170 \\
0.054 \\
0.053\end{array}$ & $\begin{array}{l}0.028 \\
0.039 \\
0.041 \\
0.022 \\
0.030\end{array}$ & $\begin{array}{l}0.28 \\
0.23 \\
0.46 \\
0.22 \\
0.09\end{array}$ \\
\hline $\begin{array}{l}\text { Mean } \\
\text { SD } \\
\text { SE }\end{array}$ & $\begin{array}{r}1.04 \\
\pm 0.61 \\
\pm 0.27\end{array}$ & $\begin{array}{l}1,110 \\
\pm 350 \\
\pm 155\end{array}$ & $\begin{array}{l}1,180 \\
\pm 700 \\
\pm 310\end{array}$ & $\begin{array}{r}2.8 \\
\pm 0.7 \\
\pm 0.3\end{array}$ & $\begin{array}{l}2,930 \\
\pm 775 \\
\pm 350\end{array}$ & $\begin{array}{l}7,360 \\
\pm 770 \\
\pm 345\end{array}$ & $\begin{array}{r}0.092 \\
\pm 0.052 \\
\pm 0.023\end{array}$ & $\begin{array}{r}0.032 \\
\pm 0.008 \\
\pm 0.003\end{array}$ & $\begin{array}{r}0.26 \\
\pm 0.13 \\
\pm 0.06\end{array}$ \\
\hline
\end{tabular}

${ }^{*} \mathrm{MCR}^{\mathrm{T}}$ and $M \mathrm{MCR}^{\mathrm{A}}=$ metabolic clearance rate of testosterone and androstenedione; $\mathrm{P}_{\mathrm{B}} \mathrm{T}^{\mathrm{and}} \mathrm{P}_{\mathrm{B}}{ }^{\mathrm{A}}=$ blood production rate of testosterone and androstenedione; $x^{T} / x^{A}=$ conversion ratio of labeled testosterone to androstenedione $;[\rho]_{\mathrm{BB}^{\Lambda \mathrm{T}}}=$ fraction of blood androstenedione pool converted to blood testosterone pool.

where $\mathrm{C}_{\mathbf{B B}} \mathbf{A T}$ is the conversion ratio of androstenedione to testosterone in blood.

$$
[\rho]_{\mathrm{BB}^{\mathrm{AT}}}=\left(\mathrm{MCR}^{\mathrm{T}} / \mathrm{MCR}^{\mathrm{A}}\right) \times\left(\mathrm{x}^{\mathrm{T}} / \mathrm{x}^{\mathbf{A}}\right),
$$

where $[\rho]_{\mathrm{BB}^{\mathrm{AT}}}$ is the fraction of the blood androstenedione pool converted to the blood testosterone pool.

$$
\left([\rho]_{B_{B}}{ }^{\mathbf{T}} \times P_{B^{A}}\right) / P_{B^{T}}=\left(x^{T} / x^{A}\right) \times\left(i^{A} / i^{T}\right),
$$

where the expression is the fraction of the blood testosterone production that is derived from blood androstenedione production. A similar expression can be derived for androstenedione production from testosterone. The correction factor, $1-[\rho]_{\mathbf{B B}^{\mathrm{AT}}} \times[\rho]_{\mathbf{B B}^{\mathrm{TA}}}$, for the amount of precursor originating from product has been ignored, since the product of the two $[\rho]$ values is approximately 0.03 .

Errors of the method. The errors of the rates of radioactive steroid infusions determined from the counting errors and from the observed variability of pump tubing effluent were $\pm 4 \%$ for $R^{T}$ and $5 \%$ for $R x^{A}$. The theoretical errors of the radioactive steroid levels in plasma calculated from counting errors and specific activity determinations were $\pm 4 \%$, $\pm 4 \%$, and $\pm 11 \%$ for these determinations $( \pm 3.0, \pm 4.4$, and $\pm 9.9 \%)$. The errors of the calculated values were as follows: $\mathrm{MCR}^{\mathrm{T}}, \pm 5.7 \%$; MCRA, $\pm 6.0 \% ; \mathrm{P}_{\mathrm{B}}{ }^{\mathrm{T}}, \pm 35 \% ; \mathrm{P}_{\mathrm{B}}{ }^{A}, \pm 18 \% ; \mathrm{x}^{\mathrm{T}} / \mathrm{x}^{\mathrm{A}}$, $\pm 11.8 \% ;[\rho]_{\mathrm{BB}}{ }^{\mathrm{AT}}, \pm 14.4 \%$. The larger error of $\mathrm{P}_{\mathrm{B}}{ }^{\mathrm{T}}$ was calculated for plasma testosterone levels in normal women. 
This error is $21 \%$ when the plasma testosterone level is in the range of $0.1 \mu \mathrm{g}$ per $100 \mathrm{ml}$.

\section{Results}

Plasma steroids. The mean plasma testosterone concentration of $0.40 \mu \mathrm{g}$ per $\mathrm{L}$ in the five normal ovulatory women (Table IV) was the same as that of 20 normal women previously reported from this laboratory $(0.37 \pm 0.02 \mathrm{SE} \mu \mathrm{g}$ per $\mathrm{L}$; range, 0.20 to $0.70 \mu \mathrm{g}$ per $\mathrm{L})(12)$. The mean plasma levels in women with idiopathic hirsutism $(0.81 \pm 0.09 \mathrm{SE} \mu \mathrm{g}$ per L) and with polycystic ovaries $(1.04 \pm 0.27 \mathrm{SE} \mu \mathrm{g}$ per $\mathrm{L})$ were higher than the normal levels $(p<0.01)$. Despite this difference four of the 13 hirsute women had plasma testosterone levels in the normal range.

The mean plasma androstenedione level in the five normal women $(1.5 \pm 0.22 \mathrm{SE} \mu \mathrm{g}$ per $\mathrm{L})$ was not different from the mean of 20 normal women previously reported $(1.67 \pm 0.09 \mathrm{SE} \mu \mathrm{g}$ per L; range, 0.9 to $2.1 \mu \mathrm{g}$ per L) (12). The androstenedione levels in both hirsute groups were significantly greater than those of normal women $(p<0.05)$. As with the testosterone levels, the ranges overlapped.

Metabolic clearance rates. The primary data from all the studies are summarized in Table III. Adequate amounts of tritium and ${ }^{14} \mathrm{C}$ were present in each steroid, and the counting ratios were satisfactory. The mean $\mathrm{MCR}^{\mathrm{T}}$ of normal women measured by the constant infusion technique was significantly less than the means of the subjects with

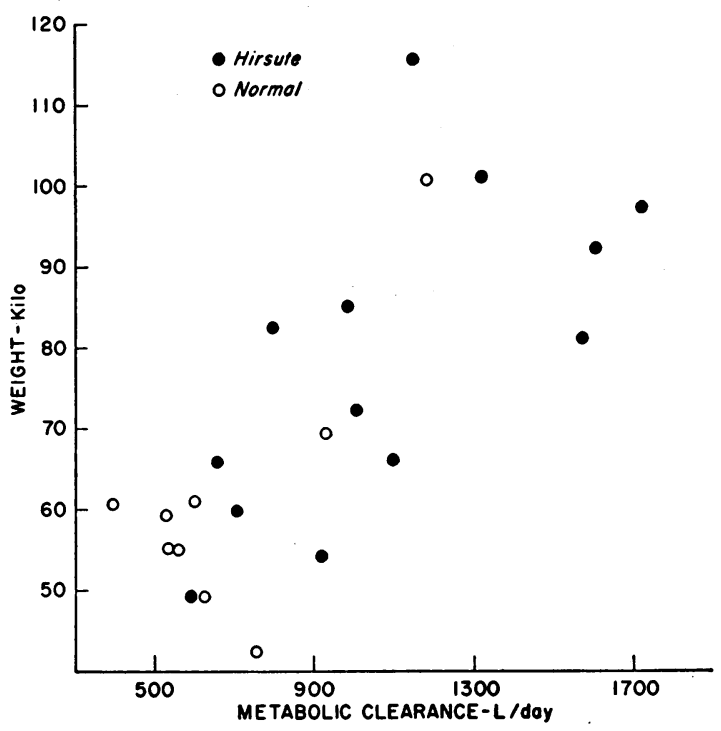

Fig. 2. Correlation of the testosterone metabolic CLEARANCE RATE (MCR ${ }^{\mathbf{T}}$ ) WITH BODY WEIGHT. The $\mathbf{r}$ equals 0.79 with $95 \%$ confidence limits of 0.5 to 0.9 .

idiopathic hirsutism or polycystic ovaries ( $p<$ 0.01) (Table IV). Because the higher clearance rates occurred in heavier women, we examined $\mathrm{MCR}^{\mathrm{T}}$ as a function of body weight (Figure 2) and found the $\mathrm{r}$ to be 0.79 with $95 \%$ confidence limits of 0.5 to 0.9 . In view of these findings and since the calculated metabolic clearance rate depends not only on rate of steroid metabolism but on its volume of distribution, it is appropriate to correct $\mathrm{MCR}^{\mathrm{T}}$ for body size before comparing it among groups. We have elected to express

TABLE V

The metabolic clearance rates of testosterone and androstenedione

\begin{tabular}{|c|c|c|c|c|c|}
\hline $\begin{array}{l}\text { Subjects } \\
\text { No. }\end{array}$ & $\mathbf{M C R}^{\mathbf{T}}$ & $\mathrm{MCR}^{\mathrm{T}} / \mathrm{m}^{2}$ & $\begin{array}{l}\mathrm{MCRT} / \mathrm{m}^{2} \\
\log \mathrm{PB}^{\mathrm{T}}\end{array}$ & MCRA & $\mathrm{MCR}^{\mathrm{A}} / \mathrm{m}^{2}$ \\
\hline$m^{2}$ & $L / d a y$ & & & $L / d a y$ & \\
\hline$\underset{5}{\text { Normal women }} 1.53 \pm 0.04^{*}$ & $590 \pm 44$ & $390 \pm 40$ & $161 \pm 15$ & $2,070 \pm 260$ & $1,360 \pm 185$ \\
\hline $\begin{array}{c}\text { Idiopathic hirsutism } \\
8\end{array}$ & $1,080 \pm 145 \dagger$ & $600 \pm 60 \ddagger$ & $202 \pm 18$ & $2,300 \pm 160$ & $1,240 \pm 53$ \\
\hline $\begin{array}{l}\text { Polycystic ovaries } \\
5\end{array} 1.95 \pm 0.07 \dagger$ & $1,110 \pm 155 \dagger$ & $568 \pm 84$ & $185 \pm 26$ & $2,930 \pm 350$ & $1,550 \pm 96$ \\
\hline $\begin{array}{l}\text { All hirsute women } \\
13 \quad 1.83 \pm 0.06 \dagger\end{array}$ & $1,090 \pm 140 \dagger$ & $588 \pm 47 \ddagger$ & $196 \pm 12$ & $2,540 \pm 178$ & $1,360 \pm 65$ \\
\hline$\underset{6}{\text { Normal men }} 1.98 \pm 0.12 \dagger$ & $1,240 \pm 136 \dagger$ & $627 \pm 60 \ddagger$ & $162 \pm 16$ & & \\
\hline
\end{tabular}

* Mean \pm standard error.

$\dagger$ Significantly different from normal women $(p<0.01)$.

$\ddagger$ Significantly different from normal women $(\mathrm{p}<0.05)$. 
$\mathrm{MCR}^{\mathrm{T}}$ as a function of surface area. Even with this correction, $\mathrm{MCR}^{\mathrm{T}}$ per square meter was higher in the hirsute patients than in the normal women $(p<0.05)$ (Table V). Calculations based on body weight rather than surface area gave similar results. These data suggested that some factor in addition to body size influenced the $\mathrm{MCR}^{\mathrm{T}}$ of hirsute women.

We therefore examined the relationship between $\mathrm{MCR}^{\mathbf{T}}$ and several parameters of testosterone metabolism. The logarithm of the blood testosterone production rate $\left(\log \mathrm{P}_{\mathbf{B}} \mathbf{T}\right)$ was correlated positively with $\mathrm{MCR}^{\mathrm{T}} \quad(\mathrm{r}=0.65)$ and with $\mathrm{MCR}^{\mathrm{T}}$ per square meter $(\mathrm{r}=0.55)$ with rather wide confidence limits. When the $\mathrm{MCR}^{\mathrm{T}}$ was corrected for surface area and $\log \mathrm{P}_{\mathrm{B}}{ }^{\mathrm{T}}$, then the resulting expression $\mathrm{MCR}^{\mathbf{T}}$ per square meter per $\log \mathrm{P}_{\mathbf{B}}{ }^{\mathrm{T}}$ was the same for all groups (Table V).

Since we found that the $\mathrm{MCR}^{\mathrm{T}}$ of men (Table V) was twice that of women, we calculated the effects of correction for surface area and testosterone production rate on $\mathrm{MCR}^{\mathbf{T}}$. When the $\mathrm{MCR}^{\mathbf{T}}$ was corrected for surface area, the $\mathrm{MCR}^{\mathrm{T}}$ per square meter of men remained significantly greater than that of women. When the expression $\mathrm{MCR}^{\mathbf{T}}$ per square meter per $\log \mathrm{P}_{\mathbf{B}}{ }^{\mathrm{T}}$ was calculated, however, the values were the same in men and women.

The MCR ${ }^{\mathrm{T}}$ of the women in group Ib was consistent with that of the other groups with the correction factors just outlined. Of interest were Patients 7 and 9, who had high plasma testosterone levels and $\mathrm{MCR}^{\mathbf{T}}$. When the $\mathrm{MCR}^{\mathbf{T}}$ was corrected by surface area and $\log \mathrm{P}_{\mathbf{B}}{ }^{\mathrm{T}}$, the $\mathrm{MCR}^{\mathrm{T}}$ per square meter per $\log \mathrm{P}_{\mathbf{B}}{ }^{\mathrm{T}}$ was the same as in the other groups.

The $M^{\prime} R^{\mathbf{A}}$ and $M^{\prime} R^{\mathbf{A}}$ per square meter are summarized in Table V. Although there was no significant difference between the $\mathrm{MCR}^{\mathbf{A}}$ of normal and hirsute women at the 0.05 level, the MCR ${ }^{\Delta}$ of the obese women was greater than that of the normal women. The variances of the means of the $\mathrm{MCR}^{\mathbf{A}}$ for each group were reduced markedly by correction for surface area.

Blood production rates. The blood production rates of testosterone and androstenedione from Table IV are summarized in Figures 3 and 4, respectively. Both $\mathrm{P}_{\mathbf{B}}{ }^{\mathrm{T}}$ and $\mathrm{P}_{\mathbf{B}}{ }^{\mathrm{T}}$ per square meter were two to four times greater in the hirsute groups than in the normal. The ranges did not overlap although some hirsute patients had plasma

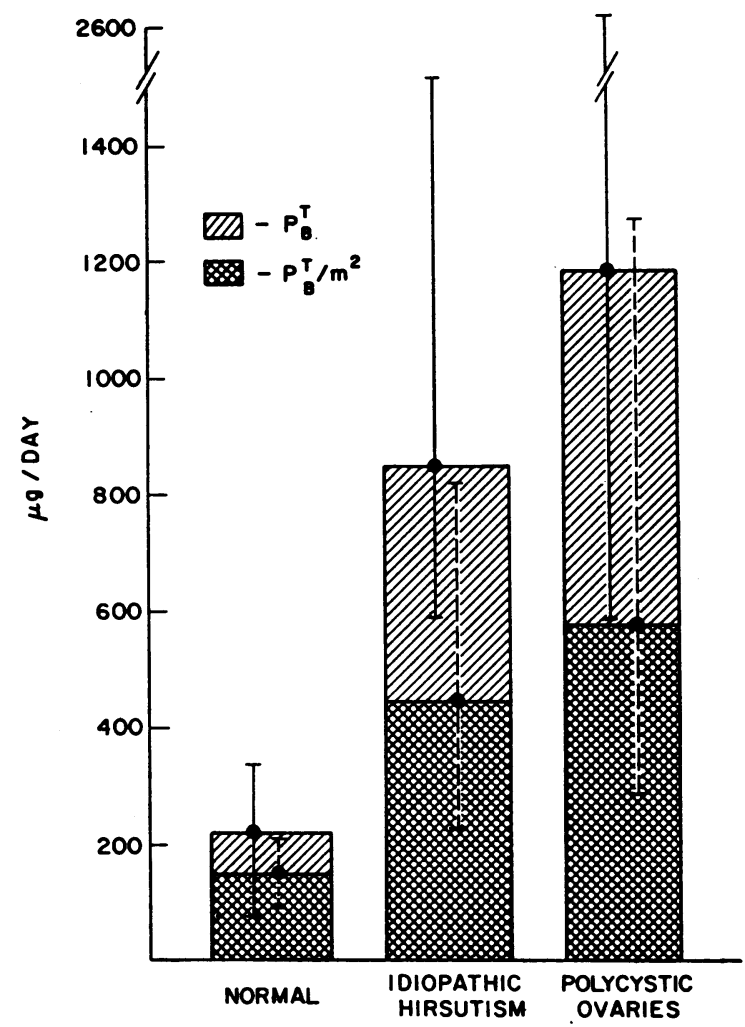

Fig. 3. Testosterone blood production rates $\left(P_{B}{ }^{T}\right)$ AND BLOOD PRODUCTION RATES PER SQUARE METER OF BODY SURFACE $\left(\mathrm{P}_{\mathbf{B}} \mathrm{T} / \mathrm{m}^{2}\right)$ IN NORMAL AND HIRSUTE WOMEN. Mean and range.

testosterone levels within the normal range. Similarly, $\mathrm{P}_{\mathbf{B}}{ }^{\mathbf{A}}$ and $\mathrm{P}_{\mathbf{B}}{ }^{\mathbf{A}}$ per square meter were twice as great in the hirsute women.

Conversion ratios, $[\rho]$ values, and fraction of $P_{B}{ }^{T}$ from $P_{B}{ }^{A}$. The conversion ratios of labeled androstenedione to testosterone, $\mathrm{x}^{\mathrm{T}} / \mathrm{x}^{\mathrm{A}}$, during the infusion of radioactive androstenedione are summarized in Table IV. Ratios of $\mathrm{x}^{\mathrm{T}} / \mathrm{x}^{\mathbf{A}}$ were the same in the normal and polycystic ovary groups, but $x^{T} / x^{\mathbf{A}}$ was significantly lower in the normal than in the idiopathic hirsutism group $(p<0.01)$. Despite this, the fraction of the blood androstenedione converted to blood testosterone, $[\rho]_{\mathbf{B B}}{ }^{\mathbf{A T}}$, was the same in the three groups, the means ranging from 0.031 to 0.033 . Since $P_{B}{ }^{A}$ was greater in the hirsute subjects, the amount of blood testosterone produced from blood androstenedione $\left([\rho]_{\mathbf{B B}}{ }^{\mathbf{A T}} \times \mathrm{P}_{\mathbf{B}}{ }^{\mathbf{A}}\right)$ was higher. It is apparent that since the fractional conversion rate, $[\rho]_{\mathbf{B B}}{ }^{\mathbf{A T}}$, was the same among all groups, the per cent of blood testosterone derived from blood 


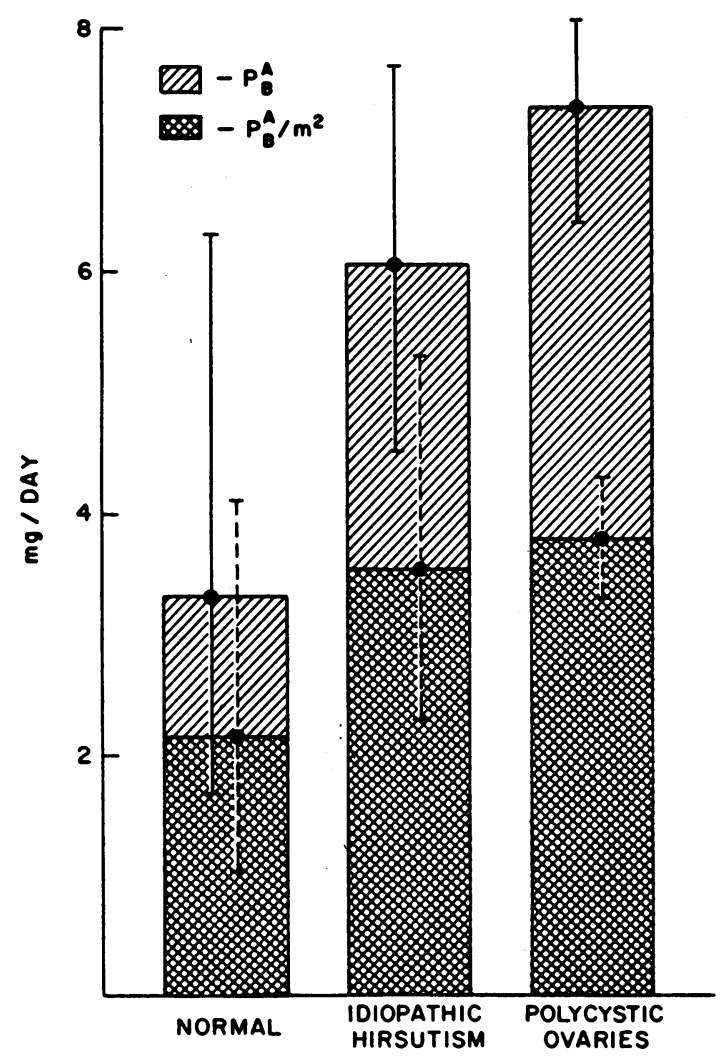

Fig. 4. ANDrostenedione BLOOD PRODUCtion RATES $\left(\mathrm{P}_{\mathrm{B}}{ }^{\Delta}\right)$ AND BLOOD PRODUCTION RATES PER SQUARE METER OF BODY SURFACE $\left(\mathrm{P}_{\mathrm{B}}{ }^{\Delta} / \mathrm{m}^{2}\right)$ IN NORMAL AND HIRSUTE WOMEN. Mean and range.

androstenedione is directly proportional to $\mathrm{P}_{\mathrm{B}} \mathrm{A} /$ $\mathrm{P}_{\mathbf{B}} \mathbf{T}^{\mathrm{T}}$. In normal subjects, this ratio was 14.3 , and $49 \%$ of blood testosterone was derived from blood androstenedione. In the idiopathic hirsutism and polycystic ovary groups, $\mathrm{P}_{\mathbf{B}} \mathbf{A}^{\mathbf{A}} / \mathrm{P}_{\mathbf{B}}{ }^{\mathbf{T}}$ were 7.3 and 6.2 , respectively, so that a smaller per cent of blood testosterone originated from blood androstenedione (Table IV). Thus the hirsute subjects must have had either a greater secretion of testosterone or a larger synthesis from some precursor that did not enter the plasma androstenedione pool.

Comparison of ${ }^{3} \mathrm{H} /{ }^{14} \mathrm{C}$ ratios of plasma and testosterone and urinary testosterone glucuronide. It has been shown $(7,13)$ that only a small fraction of testosterone synthesized from blood androstenedione reaches the blood testosterone pool, and it was found that the fractional conversion of blood androstenedione to urinary testosterone glucuronoside $\left([\rho]_{\mathbf{B O}}{ }^{\mathbf{A T}}\right)$ was greater than $[\rho]_{\mathbf{B B}}{ }^{\mathbf{A T}}$. The large differences between the ${ }^{3} \mathrm{H} /{ }^{14} \mathrm{C}$ ratios of plasma testosterone and urinary testosterone glucuronoside (Table VI) re-emphasize this. The ratios of the ${ }^{3} \mathrm{H} /{ }^{14} \mathrm{C}$ of testosterone glucuronoside to the ${ }^{3} \mathrm{H} /{ }^{14} \mathrm{C}$ of plasma testosterone were not the same in all patients (column 6, Table VI). This demonstrates that $[\rho]_{\mathbf{B B}}{ }^{\mathbf{A T}}$ has no constant relationship to $[\rho]_{\mathrm{BU}^{\mathrm{AT}}}$. This is in accord with the suggestion (7) that most of the synthesis of plasma testosterone from androstenedione takes place in peripheral tissues other than the liver.

\section{Discussion}

Testosterone. The development of methods for the measurement of plasma testosterone levels promised solutions to several problems associated with virilization and hirsutism. Indeed, to our knowledge, whenever plasma testosterone has been determined in virilized women, the levels have been high. However, the promise of a relationship between plasma testosterone and hirsutism

TABLE VI

Isotopic ratios in urinary testosterone glucuronoside and free plasma testosterone after the infusion of androstenedione $-{ }^{3} \mathrm{H}$ and testosterone $-{ }^{14} \mathrm{C}$

\begin{tabular}{|c|c|c|c|c|c|}
\hline $\begin{array}{c}\text { (1) } \\
\text { Subject } \\
\text { no. }\end{array}$ & $\begin{array}{c}(2) \\
\text { Diagnosis }\end{array}$ & $\begin{array}{c}\text { (3) } \\
{ }^{8} \mathrm{H} / 14 \mathrm{C} \\
\text { of isotopes } \\
\text { given }\end{array}$ & $\begin{array}{c}(4) \\
{ }^{3} \mathrm{H} /{ }^{14} \mathrm{C} \\
\text { of urinary } \\
\text { testosterone } \\
\text { glucuronoside }\end{array}$ & $\begin{array}{c}(5) \\
{ }^{8} \mathrm{H} / 14 \mathrm{C} \\
\text { of plasma } \\
\text { testosterone }\end{array}$ & $\begin{array}{c}(6) \\
\text { Ratio of } \\
\text { column } 4 \\
\text { divided by } \\
\text { ratio of } \\
\text { column } 5\end{array}$ \\
\hline & & \multicolumn{4}{|c|}{$d p m$} \\
\hline 3 & Normal & 25.0 & 10.9 & 0.84 & 13 \\
\hline 5 & Normal & 28.2 & 10.9 & 0.79 & 14 \\
\hline 12 & Idiopathic hirsutism & 32.8 & 10.2 & 0.79 & 13 \\
\hline 15 & Idiopathic hirsutism & 32.8 & 15.9 & 0.78 & 20 \\
\hline 20 & Polycystic ovary & 31.9 & 20.1 & 1.12 & 18 \\
\hline 22 & Polycystic ovary & 32.1 & 7.25 & 0.89 & 8 \\
\hline
\end{tabular}


has proved illusory. In several studies of hirsute women, plasma testosterone levels ranged from normal to high $(1-6)$. Our data are similar to those previously reported; that is, although the mean plasma testosterone level differed significantly between the normal and hirsute groups, not all the patients had abnormal testosterone levels.

In contrast to the normal levels of plasma testosterone reported in various studies in hirsute subjects, testosterone production rates were higher than normal in each hirsute patient. This somewhat unexpected finding made us consider that some aspects of testosterone production or clearance in addition to plasma levels may be of significance in the development of hirsutism. The recent reports of testosterone metabolism by skin (14) may be pertinent to the clearance of testosterone, but meaningful estimates of the fraction of testosterone metabolized by skin cannot be made as yet.

The thesis has been advanced that hirsutism may be a manifestation of increased end-organ sensitivity to normal androgen levels (15). This was based on the obvious differences in the rate of development of hirsutism by women receiving testosterone. This thesis was supported further by the occurrence of normal plasma testosterone levels in some hirsute women. Our findings of a uniformly increased testosterone production rate do not support the hypothesis that differences in end-organ sensitivity are the sole determinants of hirsutism. Although this is a relatively small series, it is the only one in which' a consistent biochemical difference was observed in hirsutism.

It should not be inferred, however, that an increased testosterone production rate will be necessarily associated with hirsutism. End-organ sensitivity may be the determinant in these instances. Two of our subjects, Patients 7 and 9, had high testosterone production rates but no hirsutism.

These results differ from those previously reported from our laboratory (5) when testosterone production rates were being measured by isotope dilution into urinary metabolites. The reasons for the overestimates of testosterone production rates by this method have been discussed fully $(13,16)$. The differing results emphasize the importance of using the metabolic clearance tech- nique for meaningful assessments of testosterone production.

The extrapolation of testosterone production rates obtained by the metabolic clearance technique to estimates of 24-hour production rates should be cautious. Our patients were studied in the basal state before arising in the morning. Under these conditions, the testosterone metabolic clearance technique would be maximal; it has been shown to decrease by as much as $35 \%$ upon standing (17). Changes in metabolic clearance could thus affect plasma testosterone levels. Further, circadian variations in plasma testosterone levels in women have not been examined, and significant changes in these levels would alter the calculated 24-hour production rate. These considerations emphasize that all patients should be studied under similar metabolic conditions if comparisons are to be made.

Androstenedione. Although androstenedione has been recognized as an androgen, its quantitative importance as a precursor of plasma testosterone in women was demonstrated only recently (7). Mahesh and Greenblatt (18) reported high androstenedione levels in ovarian vein blood from women with polycystic ovaries. These studies make it imperative that any examination of androgen overproduction include an analysis of androstenedione production and conversion to testosterone.

Plasma androstenedione levels and production rates in patients with hirsutism or polycystic ovaries were about twice those of normal women. This excess androstenedione may be of ovarian origin in women with polycystic ovaries (18), but its source is unknown in patients with idiopathic hirsutism. Suppression of the adrenal cortex in a large group of hirsute women permitted Jayle, Scholler, Mauvais-Jarvis, and Métay (19) to distinguish between adrenal cortical and ovarian hirsutism. The more recent demonstration (20) that adrenal suppression markedly decreases urinary testosterone excretion in most hirsute women points to the role of the adrenal cortex in the secretion of testosterone or its precursors.

Horton and Tait (7) found that $60 \%$ of the plasma testosterone of normal women was derived from plasma androstenedione. In our control group $49 \%$ of the testosterone was so derived, which is in reasonable agreement with the former investigators. 
However, the fractional conversion of androstenedione to testosterone, $[\rho]_{\mathbf{B B}}{ }^{A T}$, was lower than that observed by Horton and Tait (7). This discrepancy is due to the lower $\mathrm{MCR}^{\mathrm{T}}$ observed in our study. It should be noted that this difference in the $\mathrm{MCR}^{\mathrm{T}}$ affects only the calculation of $\mathrm{P}_{\mathrm{B}}{ }^{\mathrm{T}}$ and $[\rho]_{\mathbf{B B}}{ }^{\mathbf{A T}}$. The $[\rho]_{\mathbf{B B}^{\mathrm{AT}}}$ was the same in all of our subjects. Therefore, the higher testosterone production rate of the hirsute patient cannot be due to increased rate of synthesis of testosterone from plasma androstenedione in the liver or other peripheral tissue. In the hirsute patients, $26 \%$ of the plasma testosterone was derived from plasma androstenedione. Thus $74 \%$ of the $830 \mu \mathrm{g}$ of plasma testosterone in women with idiopathic hirsutism and 1,180 $\mu \mathrm{g}$ in subjects with polycystic ovaries must have been either secreted or derived from precursors that did not enter the plasma androstenedione pool.

Testosterone secretion from the polycystic ovary has been demonstrated by several investigators $(3,6,18)$. In addition, the adrenal cortex has been shown to secrete testosterone in hirsute women (4).

The question of other precursors has not been examined thoroughly as yet. The secretion of possible precursors such as dehydroepiandrosterone, its sulfate, and 5 -androsten- $3 \beta, 17 \beta$-diol has been reported (21). We have estimated that as much as $50 \mu \mathrm{g}$ per day of blood testosterone production could be derived from the secretion of $10 \mathrm{mg}$ per day of dehydroepiandrosterone (22). Tait and Horton (23) have discussed fully the question of testosterone precursors other than androstenedione and concluded that their quantitative importance is small. If these considerations are correct, then the increased testosterone production rates in hirsutism are due, in large part, to testosterone secretion. Differential suppression of the adrenal cortex and ovary will be necessary to assess the relative roles of each gland in the secretion of testosterone and androstenedione. In preliminary studies in patients with hirsutism, we have observed that dexamethasone caused a significant reduction of plasma testosterone in five of nine patients and of plasma androstenedione in all nine patients.

Metabolic clearance rates and methodology. The concept (24) and methods (25) of measuring metabolic clearances have been clearly outlined by Tait and his co-workers. In a study of three men and two women (7), the testosterone metabolic clearance rates were reported to be the same, although those of the women were less than those of the men. Hudson, Dulmanis, Coghlan, and Wintour (26) reported that metabolic clearance rates of testosterone of men and women were the same, but the details of the infusion technique were not given. Southren, Tochimoto, Carmody, and Isurugi (27), using the single injection technique, found that men had a greater testosterone metabolic clearance than women and in a subsequent abstract (28) stated that the clearance rate by constant infusion in men was twice that in women. Our studies are in accord with these findings.

The reasons for the discrepancies among the groups are not immediately apparent, but several important features of this study should be emphasized.

1) Teflon tubing was used for each infusion, and the rate of infusion of isotope entering the patient was checked by monitoring the infusion at a stopcock behind the infusion needle. Levin, Friedrich, and Labotsky (29) have noted that polyethylene tubing may adsorb testosterone and androstenedione.

2) The purification of the plasma steroids was extensive in this study, each sample being purified by derivative formation and chromatography until specific activities and ${ }^{3} \mathrm{H} /{ }^{14} \mathrm{C}$ ratios agreed within $5 \%$ on the last two and generally three measurements.

3) In spite of the marked differences in MCR ${ }^{\mathrm{T}}$ among the groups studied, the $\mathrm{MCR}^{\mathbf{A}}$ was the same in each group and agreed closely with those reported by Horton and Tait (7). This is good evidence against systematic errors in the method for measuring testosterone metabolic clearance rates.

Therefore, after failing to find methodologic errors, we have accepted as fact that testosterone metabolic clearance rates are higher in men than in women and that they are higher in women with hirsutism or polycystic ovaries than in normal women. The possible reasons for this are of some interest.

Since the MCR is obtained by dividing the rate of infusion of the radioactive steroid by the plasma 
radioactivity of that steroid, the MCR will depend on the volume of distribution and the turnover rate. In the simplest case, the one compartment system, $\mathrm{MCR}=\mathrm{V}_{\gamma}$ where $\gamma$ is the turnover rate (30). Because of this, to compare the actual clearance of steroids from the plasma, one must correct the MCR by some factor proportional to volume of distribution. We have used the calculated surface area for this correction. Even after this correction, however, the MCR per square meter was higher in men and in the hirsute women than in normal women.

The linear regression of $\mathrm{MCR}^{\mathrm{T}}$ per square meter with the $\log \mathrm{P}_{\mathbf{B}}{ }^{\mathrm{T}}$ is demonstrated by the fact that the function $\mathrm{MCR}^{\mathrm{T}}$ per square meter per log $\mathrm{P}_{\mathbf{B}}{ }^{\mathrm{T}}$ was the same for each group. This correlation suggested the typical dose-response curve characteristic of most biologic assays where the response is linear only when plotted against the logarithm of the dose.

The explanation of this phenomenon can be only speculative at present. There are many studies demonstrating that hepatic enzyme systems capable of metabolizing androgens are altered by testosterone. Recently, the presence of a plasma testosterone-binding protein has been reported (31), and it was suggested that its level was higher in women than in men. This testosteronebinding protein was also observed to increase in pregnancy. Whether the presence of such a binding protein would alter testosterone metabolic clearance rates would depend on the binding affinity and capacity of the protein in relation to the plasma testosterone level. If significant amounts of testosterone were bound, the decrease in metabolic clearance rate would be analogous to the slowed cortisol turnover rates seen in women with increased levels of cortisol-binding globulin. It is of note that the patient with the lowest testosterone metabolic clearance in this study was taking norethynodrel, $5 \mathrm{mg}$ per day, and mestranol, $0.075 \mathrm{mg}$ per day. Our data could thus be interpreted as being consistent with a depression of a testosterone-binding protein by increased testosterone production.

\section{Acknowledgments}

We gratefully acknowledge the technical assistance of David Collins and Amel French.

\section{References}

1. Forchielli, E., G. Sorcini, M. S. Nightingale, N. Brust, R. I. Dorfman, W. H. Perloff, and G. Jacobson. Testosterone in human plasma. Analyt. Biochem. 1963, 5, 416.

2. Hudson, B., J. Coghlan, A. Dulmanis, M. Wintour, and I. Ekkel. The estimation of testosterone in biological fluids. 1. Testosterone in plasma. Aust. J. exp. Biol. med. Sci. 1963, 41, 235.

3. Dignam, W. J., R. J. Pion, E. J. Lamb, and H. H. Simmer. Plasma androgens in women. II. Patients with polycystic ovaries and hirsutism. Acta endocr. (Kbh.) 1964, 45, 254.

4. Burger, H. G., J. R. Kent, and A. E. Kellie. Determination of testosterone in human peripheral and adrenal venous plasma. J. clin. Endocr. 1964, 24, 432.

5. Korenman, S. G., M. A. Kirschner, and M. B. Lipsett. Testosterone production in normal and virilized women and in women with the Stein-Leventhal syndrome or idiopathic hirsutism. J. clin. Endocr. 1965, 25, 798.

6. Lloyd, C. W., J. Lobotsky, E. J. Segre, T. Kobayashi, M. L. Taymor, and R. E. Batt. Plasma testosterone and urinary 17 -ketosteroids in women with hirsutism and polycystic ovaries. J. clin. Endocr. 1966, 26, 314.

7. Horton, R., and J. F. Tait. Androstenedione production and interconversion rates measured in peripheral blood and studies on the possible site of its conversion to testosterone. J. clin. Invest. 1966, 45, 301.

8. Peterson, R. S., and C. E. Pierce. Methodology of urinary 17-ketosteroids in Lipids and the Steroid Hormones in Clinical Medicine, F. W. Saunders and F. W. Saunders, Jr., Eds. Philadelphia, J. B. Lippincott, 1960, p. 147.

9. Wilson, H., and M. B. Lipsett. Use of periodate oxidation in the clinical analysis of urine corticoids. Analyt. Biochem. 1963, 5, 217.

10. Kirschner, M. A., and M. B. Lipsett. The analysis of urinary steroids using gas-liquid chromatography. Steroids 1964, 3, 277.

11. Kirschner, M. A., M. B. Lipsett, and D. R. Collins. Plasma ketosteroids and testosterone in man: a study of the pituitary-testicular axis. J. clin. Invest. $1965,44,657$.

12. Bardin, C. W., and M. B. Lipsett. Estimation of testosterone and androstenedione in human peripheral plasma. Steroids 1967, 9, 71.

13. Korenman, S. G., and M. B. Lipsett. Is testosterone glucuronoside uniquely derived from plasma testosterone? J. clin. Invest. 1964, 43, 2125.

14. Rongone, E. L. Testosterone metabolism by human male mammary skin. Steroids 1966, 7, 489.

15. Kennedy, B. J., and I. T. Nathanson. Effect of intensive sex steroid hormone therapy in advanced breast cancer. J. Amer. med. Ass. 1953, 152, 1135. 
16. Tait, J. F., and R. Horton. Some theoretical considerations on the significance of the discrepancy in urinary and blood production rate estimates of steroid hormones, particularly in those of testosterone in young women. Steroids 1964, 4, 365.

17. Lipsett, M. B., H. Wilson, M. A. Kirschner, S. G. Korenman, L. M. Fishman, G. A. Sarfaty, and C. W. Bardin. Studies on Leydig cell physiology and pathology: secretion and metabolism of testosterone. Recent Progr. Hormone Res. 1966, 22, 245.

18. Mahesh, V. B., and R. B. Greenblatt. Steroid secretions of the normal and polycystic ovary. Recent Progr. Hormone Res. 1964, 20, 341.

19. Jayle, M. F., R. Scholler, P. Mauvais-Jarvis, and S. Métay. Excretion des steroides chez des femmes presentant un virilisme pilaire associe a des troubles du cycle menstruel. Acta Endocr. (Kbh.) 1961, 36, 375.

20. Nichols, T., C. A. Nugent, and F. H. Tyler. Glucocorticoid suppression of urinary testosterone excretion in patients with idiopathic hirsutism. J. clin. Endocr. 1966, 26, 79.

21. Wieland, R. G., C. De Courcy, R. P. Levy, A. P. $\mathrm{Zala}$, and $\mathrm{H}$. Hirschmann. $\mathrm{C}_{18} \mathrm{O}_{2}$ steroids and some of their precursors in blood from normal human adrenals. J. clin. Invest. 1965, 44, 159.

22. Korenman, S. G., and M. B. Lipsett. Direct peripheral conversion of dehydroepiandrosterone to testosterone glucuronoside. Steroids 1965, 5, 509.

23. Tait, J. F., and R. Horton. The in vivo estimation of blood production and interconversion rates of androstenedione and testosterone and the calculation of their secretion rates in Steroid Dynamics, G.
Pincus, T. Nakao, and J. F. Tait, Eds. New York, Academic Press, 1966, p. 393.

24. Tait, J. F. Review: the use of isotopic steroids for the measurement of production rates in vivo. $\mathrm{J}$. clin. Endocr. 1963, 23, 1285.

25. Tait, J. F., B. Little, S. A. S. Tait, and C. Flood. The metabolic clearance rate of aldosterone in pregnant and nonpregnant subjects estimated by both single-injection and constant-infusion methods. J. clin. Invest. 1962, 41, 2093.

26. Hudson, B., A. Dulmanis, J. P. Coghlan, and M. Wintour. The measurement of androgen production in normal subjects. Aust. Ann. Med. 1966, $15,236$.

27. Southren, A. L., S. Tochimoto, N. C. Carmody, and $\mathrm{K}$. Isurugi. Plasma production rates of testosterone in normal adult men and women and in patients with the syndrome of feminizing testes. J. clin. Endocr. 1965, 25, 1441.

28. Southren, A. L., G. G. Gordon, and S. Tochimoto. Plasma production rates of testosterone in normal men and women; a physiological study using both a single injection and constant infusion technique. J. clin. Invest. 1966, 45, 1075.

29. Levin, J., E. H. Friedrich, and J. Lobotsky. Steroid adsorption with polyethylene tubing. J. clin. Endocr. 1965, 25, 1519.

30. Tait, J. F., and S. Burstein. In vivo studies of steroid dynamics in man in The Hormones, G. Pincus, K. V. Thimann, and E. B. Astwood, Eds. New York, Academic Press, 1964, vol. 5, p. 441.

31. Pearlman, W. H., and O. Crépy. Steroid-protein interaction with particular reference to testosteronebinding by human serum. J. biol. Chem. 1967, 242, 182. 